\title{
Correction to: Epithelioid inflammatory myofibroblastic sarcoma with VCL-ALK fusion of central nervous system: case report and brief review of the literature
}

\author{
Shefali Chopra ${ }^{1}$ [D Nolan Maloney $^{2} \cdot$ Wei Lien Wang $^{2}$
}

Published online: 4 January 2022

(c) The Author(s) under exclusive licence to The Japan Society of Brain Tumor Pathology 2022

\section{Correction to: Brain Tumor Pathology \\ https://doi.org/10.1007/s10014-021-00416-z}

In the original publication of the article, the copyright holder for this article was incorrectly given as "The Author(s), under exclusive licence to The Author(s) under exclusive licence to The Japan Society of Brain Tumor Pathology" but should have been "The Author(s) under exclusive licence to The Japan Society of Brain Tumor Pathology".

The original article was updated.

Publisher's Note Springer Nature remains neutral with regard to jurisdictional claims in published maps and institutional affiliations.

The original article can be found online at https://doi.org/10.1007/ s10014-021-00416-z.

Shefali Chopra

Shefali.chopra@med.usc.edu

1 Keck Medical Center, University of Southern California, Los Angeles, CA, USA

2 The University of Texas MD Anderson Cancer Center, Houston, TX, USA 